\title{
Testosterone deficiency and replacement: Myths and realities
}

\author{
Ethan D. Grober, MD, MEd, FRCSC
}

Assistant Professor, Division of Urology, University of Toronto; Urologist, Mount Sinai Hospital and Women's College Hospital, Toronto, ON

Cite as: Can Urol Assoc J 2014;8(7-8):S145-7. http://dx.doi.org/10.5489/cuai.2309

Published online August 11, 2014.

\section{Abstract}

Testosterone deficiency, or hypogonadism, is common and may have deleterious effects on men, including decreased overall well-being, reduced sexual function and bone loss. Despite data demonstrating strong links between testosterone deficiency and significant comorbid conditions (including type 2 diabetes and metabolic syndrome as well as the health benefits of testosterone-replacement therapy [TRT]), some physicians are still hesitant to initiate these therapies. Their reluctance is based on a number of prevailing myths associating TRT with adverse prostate health and recent concerns highlighting the possibility of increased cardiovascular risk.

\section{Introduction}

An estimated $25 \%$ of men have low levels of testosterone. ${ }^{1}$ Besides being fundamental for the development and maintenance of male characteristics and male sexual organs, testosterone also has effects on most major organs, such as the brain, muscle, kidney, bone, liver and skin. Clinical consequences of testosterone deficiency, or hypogonadism, range from decreased libido and vitality, to osteoporosis ${ }^{2,3}$ (Fig. 1), as well as increased mortality. ${ }^{4}$

Testosterone deficiency is more common in men with certain disease states, including obesity, diabetes, hypertension, hyperlipidemia, asthma, chronic obstructive pulmonary disease (COPD) and prostatic disease. ${ }^{5}$ Indeed, the TIMES2 (Testosterone replacement In hypogonadal men with either MEtabolic Syndrome or type 2 diabetes) study showed that testosterone replacement therapy (TRT) improved glycemic control, lipid levels, sexual function and libido in men with type 2 diabetes and/or metabolic syndrome, with no corresponding increase in adverse events. ${ }^{6}$ Despite such data, several prevailing myths surrounding the use of TRT may prevent physicians from considering its use in patients who might benefit from this type of therapy.

One myth is that TRT contributes to worsening benign prostatic hyperplasia (BPH) and to an increase in the risk of urinary retention. In a retrospective review of 120 hypogonadal men treated with TRT over a 10-year period, TRT was actually associated with a lower risk of worsening lower urinary tract symptoms (LUTS). ${ }^{7}$ Among 52 men randomly assigned to receive TRT versus placebo for 1 year, investigators found that LUTS, flow rates and volumes voided were significantly better in the TRT group than in the placebo group. ${ }^{8}$

Another common misconception is that TRT increases a man's risk of developing prostate cancer. Importantly, TRT has not been associated with clinically significant increases in prostate-specific antigen (PSA) or an increased risk of prostate cancer. ${ }^{9-14}$ In a systematic review of published studies of TRT in men with hypogonadism, the average PSA increase after initiation of TRT was $0.3 \mathrm{ng} / \mathrm{mL}$ in hypogonadal men under 65 and $0.4 \mathrm{ng} / \mathrm{mL}$ in men over $65 .{ }^{15}$ The practice of using TRT as a "stress test" to determine whether PSA will rise or unmask clinically unapparent prostate cancer is not supported by science. ${ }^{15}$ Consequently, significant increases in PSA among men on TRT should not be solely attributed to the use of TRT and should be investigated irrespective of TRT use.

No association has been established between endogenous testosterone concentrations and PSA, or the risk of developing prostate cancer. ${ }^{16-20}$ However, among men with prostate cancer, low endogenous testosterone has been associated with adverse prognostic features, including higher stage cancer, ${ }^{21,22}$ higher Gleason scores, ${ }^{23-25}$ higher frequency of positive surgical margins, ${ }^{26}$ and decreased overall survival with metastatic disease. ${ }^{27}$

Consistent with previous smaller investigations, in a review of 103 hypogonadal men with prostate cancer and a undetectable PSA following radical prostatectomy treated with TRT, there were no differences in the rates of biochemical recurrence compared to a reference group of 50 non-hypogonadal men. Among both groups, all biochemical recurrences were 


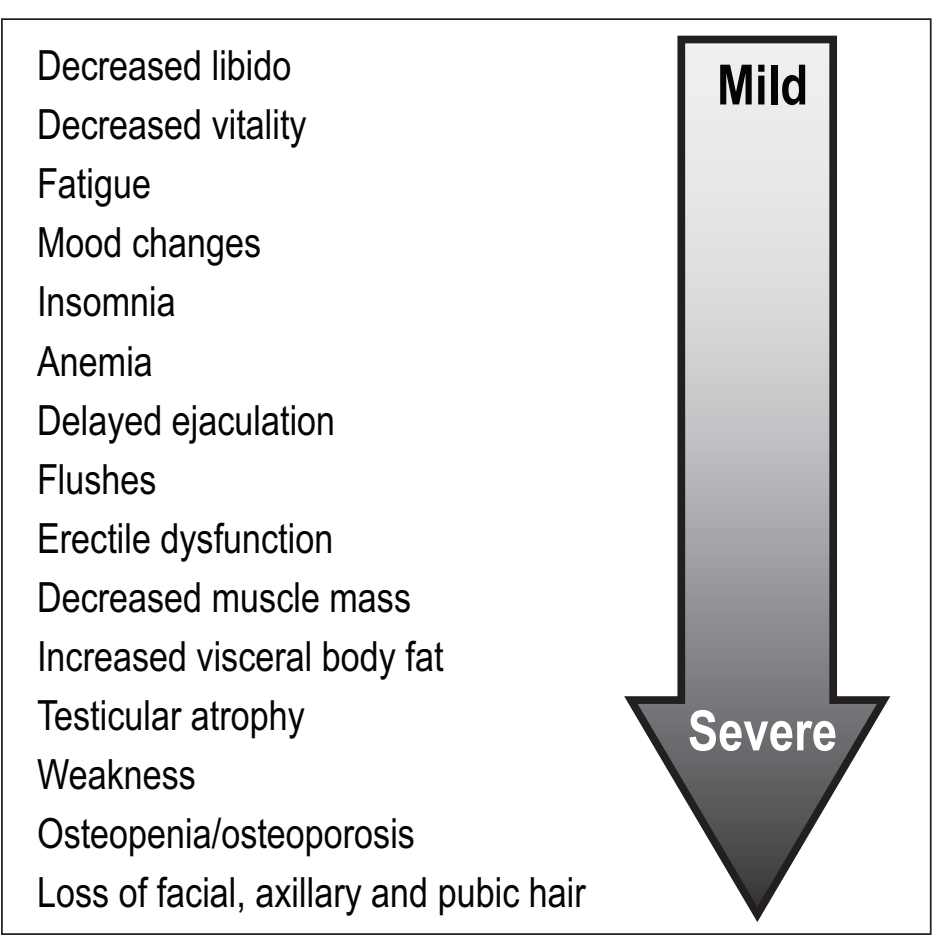

Fig. 1. Clinical manifestations of testosterone deficiency.

seen in men with high-risk features (Gleason score 8 or higher, positive surgical margins or lymph nodes), suggesting that the characteristics of the cancer themselves drive recurrences versus testosterone levels or replacement. ${ }^{28}$

In a study of 13 hypogonadal men with untreated prostate cancer undergoing active surveillance, TRT for a median of 30 months was not associated with increased PSA levels or prostate cancer progression. ${ }^{29}$

Many healthcare providers hesitate to initiate men on TRT due to the belief that these treatments increase the risk of cardiovascular (CV) events. However, the data supporting this belief are conflicting. A systematic review and meta-analysis of 30 randomized trials assessed the effect of TRT on CV events and risk factors in 1642 men with different degrees of androgen deficiency -808 were on TRT. ${ }^{30}$ The results were inconsistent across trials, but did not support an association between testosterone use and important CV effects. In another systematic review and meta-analysis of 51 randomized trials, the relative risks of myocardial infarction, arrhythmia, coronary bypass surgery and allcause mortality were not significantly increased with TRT use. ${ }^{10}$

The Testosterone in Older Men with Mobility Limitations (TOM) trial randomly assigned 209 men with mobility issues and low testosterone to 6 months' treatment with testosterone gel to improve lower extremity strength and physical function. ${ }^{31}$ In this population of older men with limitations in mobility and a high prevalence of chronic disease, testosterone gel was associated with an increased risk of $\mathrm{CV}$ events. However, these results should be interpreted with caution, as the study was not designed to assess CV disease, and more patients in the testosterone arm had hypertension or dyslipidemia at baseline. Moreover, the prescribed dose of testosterone was two times the standard starting dose and the criteria for CV events were relatively subjective and non-specific, including for example the complaint of shortness of breath, tachycardia or leg edema. The small size of the trial and the unique population should limit physicians from making broader assumptions about the safety of TRT for other patient populations.

More recently, a retrospective study of 8709 hypogonadal men who underwent coronary angiography in the Veterans Affairs system between 2005 and 2011 assessed the association between testosterone therapy and all-cause mortality, myocardial infarction (MI) or stroke. ${ }^{32}$ Overall, the unadjusted data demonstrated a protective effect of TRT use on CV risk; however, the adjusted data showed an adverse impact. Puzzling, however, is that the testosterone levels among the men on TRT versus men not on TRT were unknown. The testosterone levels among the men experiencing a $\mathrm{CV}$ event versus men without an event were unknown. Also concerning is that about 100 of the "men" in this study were later reported to be women.

\section{Conclusions}

Concerns regarding the risk of TRT on CV events need to be balanced with the evidence showing a positive impact of testosterone on heart health. Further studies are needed. Until then, we should be cautious of increasing testosterone levels too high, particularly in older men with significant risk factors for CV disease.

Competing interests: Dr. Grober is a member of the Advisory Boards for, and has received payment from Eli Lilly, Abbott and Paladin. He has also received grant funding by Eli Lilly and Paladin.

\section{References}

1. Morley JE, Charlton E, Patrick P, et al. Validation of a screening questionnaire for androgen deficiency in aging males. Metabolism 2000;49:1239-42. http://dx.doi.org/10.1053/meta.2000.8625

2. Liu PY, Swerdloff RS, Veldhuis JD. The rationale, efficacy and safety of androgen therapy in older men: Future research and current practice recommendations. J Clin Endocrinol Metab 2004;89:4789-96. http://dx.doi. org/10.1210/ic.2004-0807

3. Zitzmann M, Faber $S$, Nieschlag E. Association of specific symptoms and metabolic risks with serum testosterone in older men. J Clin Endocrinol Metab 2006;91:4335-43. http://dx.doi.org/10.1210/ic.2006-0401

4. Shores MM, Matsumoto AM, Sloan KL, et al. Low serum testosterone and mortality in male veterans. Arch Intern Med 2006;166:1660-5. http://dx.doi.org/10.1001/archinte.166.15.1660

5. Mulligan T, Frick MF, Zuraw QC, et al. Prevalence of hypogonadism in males aged at least 45 years: The HIM study. Int I Clin Pract 2006;60:762-9. http://dx.doi.org/10.1111/i.1742-1241.2006.00992.x

6. Jones TH, Arver S, Behre HM, et al; TIMES2 Investigators. Testosterone replacement in hypogonadal men with type 2 diabetes and/or metabolic syndrome (the TIMES2 study). Diabetes Care 2011;34:828-37. http:// dx.doi.org/10.2337/dc10-1233

7. Pearl JA, Berhanu D, François N, et al. Testosterone supplementation does not worsen lower urinary tract symptoms. J Urol 2013;190:1828-33. http://dx.doi.org/10.1016/i.juro.2013.05.111

8. Shigehara K, Sugimoto K, Konaka H, et al. Androgen replacement therapy contributes to improving lower urinary tract symptoms in patients with hypogonadism and benign prostate hypertrophy: A randomised controlled study. Aging Male 2011;14:53-8. http://dx.doi.org/10.3109/13685538.2010.518178 
Testosterone deficiency and replacement

9. Marks LS, Mazer NA, Mostaghel E, et al. Effect of testosterone replacement therapy on prostate tissue in men with late onset hypogonadism: a randomized controlled trial. JAMA 2006;296:2351-61. http://dx.doi. org/10.1001/jama.296.19.2351

10. Fernández-Balsells MM, Murad MH, Lane $M$, et al. Adverse effects of testosterone therapy in adult men: a systematic review and meta-analysis. J Clin Endocrinol Metab 2010;95:2560-75. htrp://dx.doi.org/10.1210/ ic.2009-2575

11. Raynaud JP, Gardette J, Rollet J, et al. Prostate-specific antigen (PSA) concentrations in hypogonadal men during 6 years of transdermal testosterone treatment. BJU Int 2013;111:880-90. hittp://dx.doi.org/10.1111/ j.1464-410X.2012.11514.x

12. Khera $M$, Bhattacharya RK, Blick $G$, et al. Changes in prostate specific antigen in hypogonadal men after 12 months of testosterone replacement therapy: Support for the prostate saturation theory. J Urol 2011;186:100511. http://dx.doi.org/10.1016/i.juro.2011.04.065

13. Coward RM, Simhan J, Carson CC 3rd. Prostate-specific antigen changes and prostate cancer in hypogonadal men treated with testosterone replacement therapy. BJU Int 2009;103:1179-83. http://dx.doi.org/10.1111/ j. $1464-410 X .2008 .08240 . x$

14. Shabsigh R, Crawford ED, Nehra A, et al. Testosterone therapy in hypogonadal men and potential prostate cancer risk: a systematic review. Int I Impot Res 2009;21:9-23. http://dx.doi.org/10.1038/iiir.2008.31

15. Bhasin $S$, Singh AB, Mac RP, et al. Managing the risks of prostate disease during testosterone replacement therapy in older men: Recommendations for a standardized monitoring plan. J Androl 2003;24:299-311.

16. Roddam AW, Allen NE, Appleby P, et al.; Endogenous Hormones and Prostate Cancer Collaborative Group. Endogenous sex hormones and prostate cancer: a collaborative analysis of 18 prospective studies. J Natl Cancer Inst 2008;100:170-83. hittp://dx.doi.org/10.1093/inci/dim323

17. Monath JR, McCullough DL, Hart $\mathrm{L}$, et al. Physiologic variations of serum testosterone within the normal range do not affect serum prostate-specific antigen. Urology 1995;46:58-61. http://dx.doi.org/10.1016/ S0090-4295(99)80159-9

18. Mohr BA, Feldman HA, Kalish LA, et al. Are serum hormones associated with the risk of prostate cancer? Prospective results from the Massachusetts Male Aging Study. Urology 2001;57:930-5. http://dx.doi. org/10.1016/S0090-4295(00)01116-X

19. Stattin $P$, Lumme $S$, Tenkanen $L$, et al. High levels of circulating testosterone are not associated with increased prostate cancer risk: a pooled prospective study. Int J Cancer 2004;108:418-24. http://dx.doi.org/10.1002/ iic. 11572

20. Severi G, Morris HA, Maclnnis RJ, et al. Circulating steroid hormones and the risk of prostate cancer. Cancer Epidemiol Biomarkers Prev 2006;15:86-91. http://dx.doi.org/10.1158/1055-9965.EPl-05-0633

21. Massengill JC, Sun L, Moul JW, et al. T. Pretreatment total testosterone level predicts pathological stage in patients with localized prostate cancer treated with radical prostatectomy. J Urol 2003;169:1670-5. http:// dx.doi.org/10.1097/01.ju.0000062674.43964.d0
22. Isom-Batz G, Bianco FJ Jr, Kattan MW, et al. Testosterone as a predictor of pathological stage in clinically localized prostate cancer. J Urol 2005;173:1935-7. hittp://dx.doi.org/10.1097/01.ju.0000158040.33531.e7

23. Hoffman MA, DeWolf WC, Morgentaler A. Is low serum free testosterone a marker for high grade prostate cancer? J Urol 2000;163:824-7. http://dx.doi.org/10.1016/S0022-5347(05)67812-3

24. Botto $H$, Neuzillet $Y$, Lebret $T$, et al. High incidence of predominant Gleason pattern 4 localized prostate cancer is associated with low serum testosterone. J Urol 2011;186:1400-5. http://dx.doi.org/10.1016/i. juro.2011.05.082

25. Dai B, Qu Y, Kong Y, et al. Low pretreatment serum total testosterone is associated with a high incidence of Gleason score 8-10 disease in prostatectomy specimens: Data from ethnic Chinese patients with localized prostate cancer. BJU Int 2012;110:E667-72. http://dx.doi.org/10.1111/j.1464-410X.2012.11465.x

26. Teloken C, Da Ros CT, Caraver F, et al. Low serum testosterone levels are associated with positive surgical margins in radical retropubic prostatectomy: Hypogonadism represents bad prognosis in prostate cancer. J Urol 2005;174:2178-80. http://dx.doi.org/10.1097/01.ju.0000181818.51977.29

27. Chodak GW, Vogelzang NJ, Caplan RJ, et al. Independent prognostic factors in patients with metastatic (stage D2) prostate cancer. The Zoladex Study Group. JAMA 1991;265:618-21. http://dx.doi.org/10.1001/ jama.1991.03460050072023

28. Pastuszak AW, Pearlman AM, Lai WS, et al. Testosterone replacement therapy in patients with prostate cancer after radical prostatectomy. J Urol 2013;190:639-44. http://dx.doi.org/10.1016/i.juro.2013.02.002

29. Morgentaler A, Lipshultz LI, Bennett R, et al. Testosterone therapy in men with untreated prostate cancer. J Urol 2011;185:1256-60. http://dx.doi.org/10.1016/i.juro.2010.11.084

30. Haddad RM, Kennedy CC, Caples SM, et al. Testosterone and cardiovascular risk in men: A systematic review and meta-analysis of randomized placebo-controlled trials. Mayo Clin Proc 2007;82:29-39. http://dx.doi. org/10.1016/50025-6196(11)60964-6

31. Basaria S, Coviello AD, Travison TG, et al. Adverse events associated with testosterone administration. N Engl J Med 2010;363:109-22. http://dx.doi.org/10.1056/NEJMoa1000485

32. Vigen R, O'Donnell Cl, Barón AE, et al. Association of testosterone therapy with mortality, myocardial infarction, and stroke in men with low testosterone levels. JAMA 2013;310:1829-36. http://dx.doi.org/10.1001/ jama.2013.280386

Correspondence: Dr. Ethan Grober, Murray Koffler Urologic Wellness Centre, 60 Murray St., $6^{\text {th }}$ Floor, Box 19, Toronto, ON M5T 3L9; fax: 416-586-8354; egrober@mtsinai.on.ca 